\title{
Seven-Year Follow-Up of a Juvenile Female with Papillary Thyroid Carcinoma with Poor Outcome, BRAF Mutation and Loss of Expression of lodine-Metabolizing Genes
}

\begin{abstract}
Background: Recent studies reported that BRAF V600E mutation, the most prevalent genetic event found in papillary thyroid carcinoma, is an independent poor prognostic marker. Additionally, it correlates with a less differentiated tumor stage due to reduced expression of key genes involved in iodine metabolism. We previously described a patient with BRAF V600E mutation in primary tumor and a new mutation (V600E+K601del) in the matched-lymph node metastases. In the present study we report an unusual clinical behavior of PTC and correlate with BRAF mutational status and level of expression of TSHR and NIS. Methods: Quantitative PCR (qPCR) was used to evaluate the NIS and TSHR level of expression in matched papillary thyroid carcinoma and adjacent normal tissue. Results: In this study, we presented a seven-year follow up of a juvenile papillary thyroid carcinoma patient who had an aggressive tumor harboring BRAF mutation, and failed to conventional therapy. We found a markedly decrease of NIS and TSHR expression in primary PTC compared to adjacent normal thyroid tissue. Conclusion: Our findings suggest that BRAF mutational status and decreased NIS and TSHR expression in this patient may reduce radioiodine uptake and lead to a negative response to radioiodine therapy. (Arq Bras Endocrinol Metab 2008; 52/8:1313-1316)
\end{abstract}

Keywords: Papillary thyroid carcinoma; BRAF mutation, NIS and TSHR

\section{RESUMO}

Sete Anos de Seguimento de uma Paciente Jovem com Carcinoma Papílfero de Tireóide e Mutação de BRAF e Perda de Expressão de Genes do Metabolismo de lodo.

Introdução: Estudos recentes demonstraram que a mutação V600E no gene $B R A F$ é o evento genético mais freqüentemente encontrado em carcinoma papilífero da tiróide e um marcador de prognóstico independente. Adicionalmente, esta alteração genética tem sido correlacionada com a redução de expressão de genes envolvidos no metabolismo do iodo. Previamente, nosso grupo descreveu uma paciente com a mutação V600E no gene BRAF no tumor primário e uma mutação nova (V600E+K601del) em metástases pareadas. Neste estudo, reportamos um carcinoma papilífero com um comportamento clínico incomum e correlacionamos com a presença de mutação no gene $B R A F$ e os níveis de expressão de TSHR e NIS. Método: Análise de expressão dos genes NIS e receptor de TSH (TSHR) através da técnica de PCR em tempo real. Resultados: Descrevemos sete anos de acompanhamento de uma paciente jovem que apresentava um tumor com comportamento agressivo e baixa resposta aos tratamentos convencionais. Uma acentuada diminuição da expressão do TSHR e a ausência de expressão de NIS foram observadas no tumor primário desta paciente quando comparada com o tecido tiroidiano normal adjacente. Conclusão: Nossos dados sugerem que as mutações encontradas nesta paciente no gene BRAF com conseqüente perda de expressão dos genes NIS e TSHR podem ter reduzido a captação de iodo radioativo e a resposta ao tratamento. (Arq Bras Endocrinol Metab 2008; 52/8:1313-1316)

Descritores: Carcinoma papilífero da tiróide; Mutação nos genes BRAF, NIS e TSHR clinical case report

\author{
Gisele Oler \\ Claudia D. Nakabashi \\ Rosa Paula M. Biscolla \\ Janete M. CeruttI
}

Genetic Bases of Thyroid Tumor Laboratory, Division of Genetics and Division of Endocrinology, Federal University of São Paulo, São Paulo, SP, Brazil.

Received in 29/8/2008

Accepted in 15/10/2008 


\section{INTRODUCTION}

he activating point mutation $\mathrm{V} 600 \mathrm{E}$ in exon 15 of $B R A F$ gene is the most common and specific genetic event in papillary thyroid carcinomas (PTC) $(1,2)$. It has been suggested that BRAF V600E mutation is a prognostic biomarker that predicts poor outcome, as early recurrences are more frequent, tumors are less differentiated and have a lower survival rate (3-5). Some groups have suggested that its impact on clinical outcome may be associated with reduced expression of key genes involved in iodine metabolism ${ }^{6}$. In fact, high risk of recurrence was associated with loss of NIS-mediated ${ }^{131}$ I uptake (7).

We have previously investigated BRAF mutational status in metastatic and non-metastatic papillary thyroid carcinomas $(8,9)$. We have not only found an association between $B R A F$-mutation and a more aggressive phenotype but also identified a new $B R A F$ mutation in tree lymph node metastases from PTC (8). In this study we reported a seven-year follow-up in one of those patients where BRAF V600E was found in primary tumor and V600E+K601 del in matched lymph node metastases. The uniqueness of this case is the combination of a juvenile papillary thyroid carcinoma which had local recurrence and reduced ${ }^{131} \mathrm{I}$ uptake and BRAF V600E mutation. Since loss of expression of iodinemetabolizing genes may be associated with loss of their ability to trap ${ }^{131}$ I and less differentiate tumor, we investigated the TSHR and NIS expression in primary tumor and compared to matched-normal thyroid.

\section{SUBJECTS AND METHODS}

\section{Case report}

An 18-year-old female was admitted to the Department of Endocrinology at Federal University of São Paulo in April 2001 after noticing a thyroid nodule $(3,5 \mathrm{~cm})$ at the left lobe. Fine needle aspiration cytology (FNAC) was performed and cytological examination was suggestive for papillary thyroid carcinoma. In July 2001 she underwent a total thyroidectomy and level VI lymph node dissection. Histological examination of the tumor assigned the diagnosis of classic papillary thyroid carcinoma. Six lymph nodes presented metastasis of papillary thyroid carcinoma. According to American Joint Committee on Cancer Staging system tumor was classified as pT2NlaMx (10). After surgery, $100-\mathrm{mCi}^{131} \mathrm{I}$ was administered for therapeutic purposes and she presented a negative post dose ${ }^{131} \mathrm{I}$ WBS (whole body scan). At that time, the TSH level was above $30 \mu \mathrm{IU} / \mathrm{mL}$ and serum thyroglobulin was $27 \mathrm{ng} / \mathrm{mL}$. During follow-up the $\mathrm{Tg}$ remained 1.2-5.9 ng/mL under TSH suppression and she had negative neck ultrasound (US). At two-years follow up, ultrasound-guided FNA cytology revealed the presence of lymph node metastases. The patient underwent surgery for lymph node dissection (levels II to V). Pathological findings confirmed the presence of metastasis in 7 out of 18 lymph nodes. Four months after surgery, as she presented serum thyroglobulin $28.2 \mathrm{ng} /$ $\mathrm{mL}$ in hypothyroidism $(\mathrm{TSH}=98 \mu \mathrm{IU} / \mathrm{mL})$, she was treated with a high dose of radioiodine $(450 \mathrm{mCi})$. The post dose WBS showed a selective uptake at the anterior cervical region. In the last three years, $\mathrm{Tg}$ and anti-Tg antibody remained undetectable with suppressive L-T4 therapy and negative cervical US. Since Tg remain undetectable under TSH suppression, the patient performed a WBS and measurement of Tg under hypothyroidism ( TSH $=107 \mu \mathrm{IU} / \mathrm{mL}$ ). WBS was negative and the $\mathrm{Tg}$ increased to $11.4 \mathrm{ng} / \mathrm{mL}$ The cervical US revealed a suspicious level IV lymph node in the right cervical side which was confirmed by FNAC as a metastatic lymph node. The patient is expected to undergo her third surgery. After that we will re-evaluate whether the patient should be treated with additional doses of radioiodine or if just thyroid suppressive therapy in the follow-up is the treatment of choice.

All diagnostic procedures were performed in accordance with the regulations of the local Ethics Committee. Written informed consent was obtained from the patient.

\section{Molecular study}

$B R A F$ mutation screening was performed by direct sequencing at the RNA level (8). As described, this patient presented the BRAF V600E mutation in the primary tumor and the BRAF V600E+K6001 del mutation in the lymph node metastasis. At that time, distinct lymph node metastases were screened for $B R A F$ mutation and both, the new mutation and the V600E were found in different lymph node metastasis.

As BRAF-mutated tumors were described as tumors with no avidity for ${ }^{131} \mathrm{I}$ uptake, as most of recurrences, we investigated the NIS and TSHR expression in primary tumor and matched-normal thyroid by quantitative PCR (qPCR). To this end, RNA extraction and cDNA synthesis was performed as described before (11). An aliquot of cDNA was used in a $20 \mu \mathrm{L}$ PCR reaction containing SYBR Green PCR Master 
Mix (PE Applied Biosystems, Foster City, CA) and 200 $\mathrm{nM}$ of each primer for the target or control gene (S8). Primers sequences were as follows: NIS sense: 5' CAGAACCACTCCCGGATCAA 3' and antisense: 5' ACCCACCACAAAAGTCCAGAA 3'; TSH-R sense: 5' ACATGACGTCAATCCCTGTG 3' and antisense: 5' TGAAAGCATATCCTTGGACTG 3'; $\$ 8$ sense: 5' AACAAGAAATACCGTGCCC 3 ' and antisense: 5' GTACGAACCAGCTCGTTATTAG 3'. qPCR reactions were performed in triplicate, the threshold cycle (Ct) was obtained using Applied Biosystem software and was averaged $(\mathrm{SD} \leq \mathrm{l})$. Gene expression was normalized using the control gene ribosomal protein $S 8$ as described before $(9,12)$.

NIS and TSHR expression was markedly lower in primary tumor compared to matched normal thyroid (Figure 1). Although NIS and TSHR expression in lymph node metastases can not be evaluated as tissues are not available, the lack of ${ }^{131} \mathrm{I}$ uptake may be a consequence of loss of iodine-metabolizing genes (TSHR and NIS) already identified in primary tumor.

\section{DISCUSSION}

PTC usually shows a very good prognosis, however 10$15 \%$ of patients are not cured after initial treatment. Identifying these high-risk patients at the time of diagnosis can help the choice of the most appropriate treatment and follow-up for them (13). BRAF V600E mutations has been associated with poor prognosis fac-

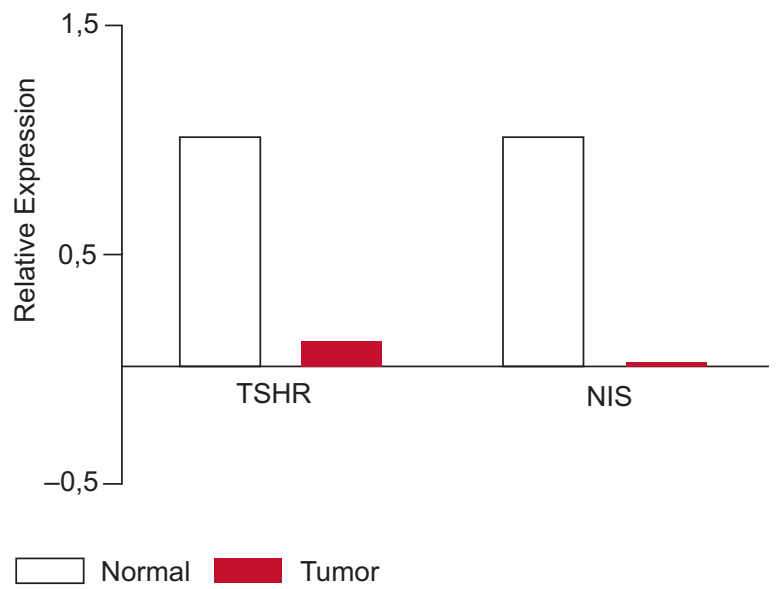

Figure 1. Relative expression of NIS and TSHR determined by qPCR. Tissue samples consists of matched normal and tumor (PTC) tissues. Transcripts were normalized by control genes (S8) and Relative Expression was calculated as described in material and methods. tors, including extrathyroidal invasion, older age, lymph node metastasis and advanced tumor stages $(14,15)$. Recently, BRAF mutation was demonstrated to be a poor prognostic factor independent from other clinicopathological features $(3,5)$.

Here, we reported a papillary thyroid carcinoma patient diagnosed at age of 18 years with a lymph node metastasis at diagnosis, high rate recurrence, reduced uptake of ${ }^{131} \mathrm{I}$ and BRAF mutation in both primary tumor and different lymph node metastases. It is worth mentioning that although the BRAF V600E mutation is the most common genetic alteration in adult papillary thyroid carcinomas most of childhood or juvenile PTCs are usually BRAF mutation-free $(16,17)$.

These findings, along with the fact that NIS expression was undetectable in the primary tumor, led us to hypothesize that her tumor may have lost the ability to trap ${ }^{131} \mathrm{I}$ and evolutes to a less differentiated state due to loss of NIS expression. Moreover, the patient had a markedly decrease of TSHR expression. Since for an effective thyroid ablation an adequate stimulation by TSH through thyroid hormone withdrawal or administration of recombinant human TSH is needed (18), we postulated that the loss of TSHR expression may also contribute to a high rate of recurrence and the reduced ${ }^{131}$ I uptake. We must note that selective uptake occurred only at a highest dose administered $(450 \mathrm{mCi})$.

Although loss of TSHR in BRAF-mutated thyroid tumors was not found (6), we recently described a significant correlation between the presence of BRAF V600E mutation and decrease of NIS and TSHR expression (19).

This data not differ from those observed by RiescoEizaguirre and cols. (7) in which PTC harboring BRAF V600E mutation had a more aggressive biological behavior characterized by early recurrences, tumors were less differentiated and had no response to ${ }^{131} \mathrm{I}$.

We hope that our data will contribute to an important question that is whether assessment of $B R A F$ status can improve the management of thyroid cancer and to decide if a FDG-PET should be considered in these patients. However, whether kinase (MEK) inhibitors could be used as coadjutant of radioiodine therapy, due to their potential to restore iodine-metabolizing genes, remain an answered question.

Acknowledgements: The São Paulo State Research Foundation (Fapesp) from grants 05/60330-8 to JMC. GO is a scholar from Fapesp, $\mathrm{CDN}$ is a scholar from $\mathrm{CNPq}$ and JMC is investigator of 
the Brazilian Research Council (CNPq). The authors declare that they have no affiliations that would constitute a financial conflict of interest relating to the subject matter of this study.

\section{REFERENCES}

1. Kimura ET, Nikiforova MN, Zhu Z, Knauf JA, Nikiforov YE, Fagin JA. High prevalence of BRAF mutations in thyroid cancer: genetic evidence for constitutive activation of the RET/PTCRAS-BRAF signaling pathway in papillary thyroid carcinoma. Cancer Res. 2003;637:1454-7.

2. Fugazzola L, Puxeddu $\mathrm{E}$, Avenia N, et al. Correlation between B-RAFV600E mutation and clinico-pathologic parameters in papillary thyroid carcinoma: data from a multicentric Italian study and review of the literature. Endocr Relat Cancer. 2006;132:455-64.

3. Kim TY, Kim WB, Rhee YS, et al. The BRAF mutation is useful for prediction of clinical recurrence in low-risk patients with conventional papillary thyroid carcinoma. Clin Endocrinol (Oxf). 2006;653:364-8.

4. Lupi C, Giannini R, Ugolini C, et al. Association of BRAF V600E mutation with poor clinicopathological outcomes in 500 consecutive cases of papillary thyroid carcinoma. J Clin Endocrinol Metab. 2007;9211:4085-90.

5. Elisei R, Ugolini C, Viola D, et al. Brafv600e Mutation and Outcome of Patients with Papillary Thyroid Carcinoma: A 15-Year Median Follow-up Study. J Clin Endocrinol Metab. 2008;93(10):3943-9.

6. Durante C, Puxeddu E, Ferretti E, et al. BRAF mutations in papillary thyroid carcinomas inhibit genes involved in iodine metabolism. J Clin Endocrinol Metab. 2007;927:2840-3.

7. Riesco-Eizaguirre G, Gutierrez-Martinez P, Garcia-Cabezas MA Nistal M, Santisteban P. The oncogene BRAF V600E is associated with a high risk of recurrence and less differentiated papillary thyroid carcinoma due to the impairment of $\mathrm{Na}+/ \mathrm{l}-\mathrm{tar}-$ geting to the membrane. Endocr Relat Cancer. 2006;131:257-69.

8. Oler G, Ebina KN, Michaluart P, Jr., Kimura ET, Cerutti J. Investigation of BRAF mutation in a series of papillary thyroid carcinoma and matched-lymph node metastasis reveals a new mutation in metastasis. Clin Endocrinol (Oxf). 2005;624:509-11.

9. Oler G, Camacho CP, Hojaij FC, Michaluart P, Jr., Riggins GJ, Cerutti JM. Gene expression profiling of papillary thyroid carcinoma identifies transcripts correlated with BRAF mutational status and lymph node metastasis. Clin Cancer Res. 2008; 1415:4735-42.
10. Wittekind C, Compton CC, Greene FL, Sobin LH. TNM residual tumor classification revisited. Cancer. 2002;949:2511-6.

11. Cerutti JM, Oler G, Michaluart Jr. P, et al. Molecular profiling of matched samples identifies biomarkers of papillary thyroid carcinoma lymph node metastasis. Cancer Res. 2007;6716:7885-92.

12. Cerutti JM, Latini FR, Nakabashi C, et al. Diagnosis of suspicious thyroid nodules using four protein biomarkers. Clin Cancer Res. 2006;1211 Pt 1:3311-8.

13. Schlumberger M, Ricard M, De Pouvourville G, Pacini F. How the availability of recombinant human TSH has changed the management of patients who have thyroid cancer. Nat Clin Pract Endocrinol Metab. 2007;39:641-50.

14. Xing M. BRAF mutation in papillary thyroid cancer: pathogenic role, molecular bases, and clinical implications. Endocr Rev. 2007;287:742-62.

15. Puxeddu E, Moretti S. Clinical prognosis in BRAF-mutated PTC. Arq Bras Endocrinol Metabol. 2007;515:736-47.

16. Lima J, Trovisco V, Soares $P$, et al. BRAF mutations are not a major event in post-Chernobyl childhood thyroid carcinomas. J Clin Endocrinol Metab. 2004;899:4267-71.

17. Kumagai $A$, Namba $H$, Mitsutake N, et al. Childhood thyroid carcinoma with BRAFT1799A mutation shows unique pathological features of poor differentiation. Oncol Rep. 2006;161:123-6.

18. Pacini F, Schlumberger M, Dralle H, Elisei R, Smit JW, Wiersinga W. European consensus for the management of patients with differentiated thyroid carcinoma of the follicular epithelium. Eur J Endocrinol. 2006;1546:787-803.

19. Oler G, Cerutti JM. High Prevalence of BRAF mutation in a Brazilian cohort of sporadic papillary thyroid carcinomas: correlation with more aggressive phenotype and decreased expression of iodide-metabolizing genes. Cancer. [in press].

\section{Correspondence to:}

\section{Janete Cerutti}

Genetic Bases of Thyroid Tumor Laboratory, Federal University of São Paulo

Rua Pedro de Toledo 669, $11^{\circ}$ andar.

04039-032 São Paulo SP, Brazil

E-mail: j.cerutti@unifesp.br 